\title{
Changes in Fungal and Bacterial Diversity During Vermicomposting of Industrial Sludge and Poultry Manure Mixture: Detecting the Mechanism of Plant Growth Promotion by Vermicompost
}

\author{
Prabhat Pramanik ${ }^{1}$, Sang Yoon Kim ${ }^{1}$ and Pil Joo Kim ${ }^{1,2 *}$ \\ ${ }^{1}$ Division of Applied Life Science (BK21 Program), Gyeongsang \\ National University, elnju, 660-701 \\ ${ }^{2}$ Division of Applied Life Sciences, Gyeongsang National University, \\ 900 Gazwa, dinju 660-701, \\ ${ }^{1}$ South Korea \\ ${ }^{2}$ Republic of Korea
}

\section{Introduction}

Agriculture is facing a challenge to develop strategies for sustainability that can conserve non-renewable natural resources, such as soil and enhance the use of renewable resources such as organic wastes. It has been estimated that more than 18 metric tons of organic sludge was generated every day in Korea in 2003 (Anonymous, 2004)while it was 105 metric tonnes per year in India (Chitdeshwari and Savithri, 2004). Among different options for recycling this sludge, application to agricultural land is probably the most reliable and costeffective technique to supply organic matter to field crops (Coker et al., 1987). But direct application of this sludge to agricultural land might cause heavy metal contamination (McGrath, 1994). Under this perspective, industrial sludge (IS) was recycled after bioremediation involving earthworms.

Unlike several chemical methods, removal of heavy metals by biological means is more specific, eco-friendly and economical. Begum and Krishna (2010) revealed that heavy metal content in organic wastes reduced after passage through earthworm guts. Therefore, industrial sludge could be recycled through vermicomposting to produce nutrient rich plant amendment. Vermicomposting is the stabilization of organic substrates by microorganisms in presence of earthworms. Though earthworms consume fungi with organic substrates to fulfil their nitrogen requirement, the viable fungal count in earthworm casts was generally higher than that of initial waste substrates during vermicomposting (Edwards and Bohlem, 1996). Ergosterol, marker molecule of fungal cell membrane, is frequently used in microbiology to quantify fungal biomass in infected media. Madan et al. (2002) estimated fungal biomass in soil by FAME assay. Hill et al. (2000) also quantified fungal specific FAME $(18: 19 \omega \mathrm{c})$ to estimate fungal biomass in compost. Yasir et al. (2009) revealed that bacterial biomass also played important role during organic matter decomposition. Muramic acid 
could be used as a marker molecule for bacterial biomass determination (King and White, 1977). The objectives of this study were to (i) standardize recycling technique of IS through vermicomposting, (ii) evaluate fungal and bacterial diversity during vermicomposting and (iii) determine plant growth promoting mechanism of vermicompost.

\section{Materials and methods}

\subsection{Substrates used and experiment design}

The vermicompost experiment was conducted in polythenelined earthen pots (5 L capacity). Poultry manure was used as the initial energy source for earthworms. Poultry manure (PM) was procured from the nearby poultry farm and industrial sludge (IS) was procured from the industrial region, Tangra, Kolkata, India. Initial chemical and microbiological properties of poultry manure and industrial sludge were presented in Table 1.

\begin{tabular}{lcc}
\hline Parameters studied & Industrial sludge & Poultry manure \\
\hline Total organic carbon $\left(\mathrm{mg} \mathrm{g}^{-1}\right)$ & 305.26 & 371.53 \\
Total Kjeldahl nitrogen $\left(\mathrm{mg} \mathrm{g}^{-1}\right)$ & 3.74 & 4.97 \\
$\mathrm{C} / \mathrm{N}$ ratio & 81.62 & 74.75 \\
Total phosphorus $\left(\mathrm{mg} \mathrm{g}^{-1}\right)$ & 3.51 & 4.18 \\
Total potassium $\left(\mathrm{mg} \mathrm{g}^{-1}\right)$ & 3.84 & 4.22 \\
Total chromium $\left(\mathrm{\mu g} \mathrm{g} \mathrm{g}^{-1}\right)$ & 859.97 & 108.49 \\
Total copper $\left(\mathrm{\mu g} \mathrm{g}^{-1}\right)$ & 471.08 & 241.92 \\
Total lead $\left(\mu \mathrm{g} \mathrm{g}^{-1}\right)$ & 64.83 & 9.07 \\
\hline
\end{tabular}

Table 1. Some chemical properties of poultry manure (PM) and industrial sludge (IS)

Fresh PM was air-dried and autoclaved at $15 \mathrm{lb} / \mathrm{in}^{2}$ pressure for $30 \mathrm{~min}$. Industrial sludge was concentration by air-drying and concentrated IS and PM mixture was used for vermicomposting. In this experiment, PM was mixed with IS in three different proportions i.e., 5\% PM $\left(\mathrm{T}_{1}\right), 10 \% \mathrm{PM}\left(\mathrm{T}_{2}\right)$ and 20\% PM $\left(\mathrm{T}_{3}\right)$ along with control $\left(\mathrm{T}_{0}\right)$ and the waste mixtures were allowed to pass through earthworm guts for vermicomposting. One and half kilogram of those waste mixtures were taken in each pot and 25 almost equal maturity (mean weight $0.48 \pm 0.06 \mathrm{~g}$ ) earthworms (Eisenia fetida) were introduced in each treatment pot. The moisture content of the organic substrates in each pot was maintained between $60 \%$ and $65 \%$ throughout the study period by sprinkling water after every 10-12 hours. The experiment was conducted following complete randomized design with three replications. Total organic carbon (TOC), total Kjeldahl nitrogen (TKN), total phosphorus (TP), total potassium (TK) and total concentration of some heavy metals $(\mathrm{Cr}, \mathrm{Cu}$ and $\mathrm{Pb}$ ) were measured initially and after completion of vermicomposting process. During vermicomposting, the feed materials from each treatment were analyzed after 15, 30, 45, 60 days after initiation of the process and on stabilization of the process (73 days) for estimating microbial biomass $C$, ergosterol, total fatty acid methyl esters (FAMEs) and muramic acid content.

\subsection{Chemical analysis}

Total organic carbon (TOC) of the vermicompost was estimated using the standard dichromate oxidation method of Nelson and Sommers (1982). Total Kjeldahl nitrogen (TKN) was estimated after digesting the sample with concentrated $\mathrm{H} 2 \mathrm{SO} 4(1: 20, \mathrm{w} / \mathrm{v})$ followed by 
distillation (Bremner and Mulvaney, 1982). Total phosphorus (TP) and total potassium (TK) were analyzed from the wet digest [tri-acid $\left(\mathrm{HNO}_{3}-\mathrm{H}_{2} \mathrm{SO}_{4}-\mathrm{HClO}_{4}\right)$ mixture was used for digestion] of vermicompost (Jackson, 1973). Total phosphorus (TP) was estimated by the colorimetric method using ammonium molybdate in hydrochloric acid and total potassium (TK) was determined by flame photometer (Bansal and Kapoor, 2000).

\subsection{Microbial analysis}

Microbial biomass was determined by the chloroform fumigation-extraction (FE) method (Vance et al., 1987). For fumigation, organic substrates were incubated with ethanol-free chloroform in desiccators. The TOC analyzer was used to determine total organic $\mathrm{C}\left(\mathrm{C}_{\mathrm{org}}\right)$ and total $\mathrm{N}$ in $0.5 \mathrm{M} \mathrm{K}_{2} \mathrm{SO}_{4}$ extracts of non-fumigated and fumigated soils. The microbial biomass carbon $(\mathrm{MBC})$ was calculated as $\mathrm{MBC}=\left(\mathrm{C}_{\text {org }}\right.$ in fumigated soil $-\mathrm{C}_{\text {org }}$ in nonfumigated soil) $/ \mathrm{k}_{\mathrm{c}}$; where, $\mathrm{k}_{\mathrm{c}}=0.33$, the factor used to convert the extracted organic $\mathrm{C}$ to MBC (Sparling and West, 1988).

An analysis for ergosterol estimation was performed with $50 \mathrm{mg}$ of lyophilized organic waste or vermicompost sample. Ergosterol was extracted from leaf litter by 30 min refluxing in alcoholic base (Gesser et al., 1991) and purified by solid-phase extraction. Final purification and quantification of ergosterol was achieved by high-performance liquid chromatography (HPLC). The system was run with HPLC grade methanol at a flow rate of $1.5 \mathrm{ml} \mathrm{min}-1$. Ergosterol eluted after 7:11 $\mathrm{min}$ and detected at $282 \mathrm{~nm}$; peak identity was checked on the basis of retention times of commercial ergosterol (98\% purity).

The FAME analysis was performed using the modified procedure of Schutter and Dick (2000). Before analysis, fresh samples were lyophilized and three grams of lyophilized sample was treated with $10 \mathrm{~mL}$ of $0.2 \mathrm{M} \mathrm{KOH}$ in methanol and incubated at $37^{\circ} \mathrm{C}$ for $1 \mathrm{hr}$. After incubation, the $\mathrm{pH}$ of the system was adjusted to 7.0 with $1.0 \mathrm{M}$ acetic acid, $10 \mathrm{~mL}$ of $\mathrm{n}$-hexane was mixed and then it was vortexed. After centrifugation at $1600 \mathrm{rpm}$ for $20 \mathrm{~min}$., $5 \mathrm{~mL}$ of $\mathrm{n}$-hexane layer was evaporated by $\mathrm{N}_{2}$ gas. The residue was dissolved in $170 \mu \mathrm{L}$ of 1:1 mixture of n-hexane and methyl t-buthyl ether with $30 \mu \mathrm{L}$ of $0.01 \mathrm{M}$ methyl nonadecanoate $\left(\mathrm{C}_{19: 0}\right)$ as internal standard for FAME and analyzed with a Hewlett-Packard 5890 Series II (Palo Alto, CA) equipped with an HP Ultra 2 capillary column (5\% diphenyl$95 \%$ dimethylpolysiloxane, $25 \mathrm{~m}$ by $0.2 \mathrm{~m}$ ) and a flame ionization detector. For FAME analysis, the oven temperature was raised from $170^{\circ} \mathrm{C}$ to $270^{\circ} \mathrm{C}$ at $5{ }^{\circ} \mathrm{C} \mathrm{min}^{-1}$ and kept at $270^{\circ} \mathrm{C}$ for 2 minutes.

Amino sugars in biomass suspensions, chloroform-fumigation-extraction (CFE) extracts and in incubated organic wastes were determined following standard method of Zhang and Amelung (1996). Sample aliquots corresponding to a about $50 \mathrm{mg}$ microbial biomass, with $100 \mu \mathrm{g}$ myo-inositol added as internal standard, were hydrolyzed with $10 \mathrm{ml}$ of $6 \mathrm{M} \mathrm{HCl}$ at $105^{\circ} \mathrm{C}$ for $8 \mathrm{~h}$. The CFE extracts were freeze-dried prior to hydrolysis. The released amino sugars were separated from impurities by neutralization with $0.4 \mathrm{M} \mathrm{KOH}$. Prior to derivatization, $100 \mu \mathrm{g}$ of methylglucamine was added as recovery standard. Derivatization was carried out according to (Guerrant and Moss, 1984). In brief, aldononitrile derivatives of the amino sugars were prepared by heating the samples in $0.3 \mathrm{ml}$ of a derivatization reagent (32 mg hydroxylamine hydrochloride $\mathrm{ml}^{-1}$ and $40 \mathrm{mg}$ 4-(dimethylamino) pyridine $\mathrm{ml}^{-1}$ in pyridine-methanol 4/1) at $75^{\circ} \mathrm{C}$ for $30 \mathrm{~min}$. After acetylation with $1 \mathrm{ml}$ of acetic anhydride at $75-80^{\circ} \mathrm{C}$ for $20 \mathrm{~min}$, dichloromethane was added, and excess derivatization reagents were removed by washing with $1 \mathrm{ml}$ of $1 \mathrm{M} \mathrm{HCl}$ and $1 \mathrm{ml}$ of water two times each. The remaining organic phase was dried under an air stream at $45^{\circ} \mathrm{C}$ and dissolved in $0.3 \mathrm{ml}$ ethyl acetatehexane (1/1). The amino sugar derivatives were separated on a HP 6890 GC equipped with 
a HP-5 fused silica column ( $30 \mathrm{~m} \times 0.25 \mathrm{~mm}$ ID with $0.33 \mu \mathrm{m}$ film thickness) and a flame ionization detector. Amino sugars were quantified using inositol as the internal standard and methylglucamine as recovery standard.

\subsection{Plant growth promotion study}

Vermicompost was extracted with ethyl acetate (vermicompost: ethyl acetate $=1: 5, \mathrm{w} / \mathrm{v}$ ) and the extract the centrifuged at $7000 \mathrm{rpm}$ for 15 minutes. The supernatant was used for radish bioassay. Five radish seeds were taken on $2 \mathrm{~mm} \times 2 \mathrm{~mm}$ sterile Whatman filter paper and $750 \mu l$ of that extract applied on radish seeds under aseptic condition and incubated at $25 \pm 1{ }^{\circ} \mathrm{C}$ for 5 days. After 5 days incubation, root and shoot length of extract applied seedlings were compared with that of control treatment.

After finding the presence of plant growth promoting compound, the ethyl acetate extract was fractionated by column chromatography using different proportions of hexane, dichloromethane and methanol to obtain 24 fractions, each of $50 \mathrm{ml}$. The fractions were then concentrated to $2-3 \mathrm{ml}$ by rotary evaporator at a temperature below $40{ }^{\circ} \mathrm{C}$. All the fractions were then tested by radish bioassay. The active three fractions (please follow the result below) were then analysed by HPLC and methanol water mixture (60: 40, v/v) was used as mobile phase for this analysis.

Vermicompost was then extracted with sterile water (vermicompost: water $=1: 100, \mathrm{w} / \mathrm{v}$ ) under aseptic condition. The extract was then serially diluted $10^{3}$ fold and incubated in broth medium with different amount of tryptophan at $30^{\circ} \mathrm{C}$ for 7 days. After incubation, cell pellets were removed by centrifugation at $6000 \mathrm{rpm}$ for 10 minutes. The supernatant was treated with Salkosky reagent and pink colour intensity was measured at $420 \mathrm{~nm}$.

\section{Results}

\subsection{Chemical properties}

Chemical analysis revealed that total concentrations of nitrogen, phosphorus and potassium of all the treatments were increased due to vermicomposting. Addition of poultry manure $(\mathrm{PM})$ significantly $(\mathrm{P}<0.05)$ increased nitrogen content in final vermicompost as compared to control treatment (Table 2). Data revealed that total nitrogen and phosphorus content of final vermicompost was increased with increasing PM proportion in initial waste mixtures. Addition of PM with IS significantly $(\mathrm{P}<0.05)$ increased total potassium content after vermicomposting, however, its values in $\mathrm{T}_{2}$ and $\mathrm{T}_{3}$ treatments were statistically at per.

\begin{tabular}{lcccc}
\hline Parameters studied & $\mathrm{T}_{0}$ & $\mathrm{~T}_{1}$ & $\mathrm{~T}_{2}$ & $\mathrm{~T}_{3}$ \\
\hline $\begin{array}{l}\text { Total organic carbon } \\
\left(\mathrm{mg} \mathrm{g}^{-1}\right)\end{array}$ & $201.0 \pm 5.4$ & $177.6 \pm 3.3$ & $168.9 \pm 4.7$ & $158.4 \pm 6.1$ \\
$\begin{array}{l}\text { Total Kjeldahl nitrogen } \\
\left(\mathrm{mg} \mathrm{g}^{-1}\right)\end{array}$ & $7.62 \pm 0.40$ & $8.35 \pm 0.43$ & $9.47 \pm 0.23$ & $9.91 \pm 0.49$ \\
$\begin{array}{l}\text { Total phosphorus } \\
\left(\mathrm{mg} \mathrm{g}^{-1}\right)\end{array}$ & $7.05 \pm 0.41$ & $8.75 \pm 0.56$ & $9.23 \pm 0.44$ & $9.89 \pm 0.39$ \\
Total potassium $\left(\mathrm{mg} \mathrm{g}^{-1}\right)$ & $6.89 \pm 0.49$ & $8.16 \pm 0.33$ & $8.94 \pm 0.40$ & $9.23 \pm 0.57$ \\
Total chromium $\left(\mu \mathrm{g} \mathrm{g}^{-1}\right)$ & $618.2 \pm 21.7$ & $573.4 \pm 14.9$ & $559.41 \pm 17.5$ & $548.7 \pm 15.4$ \\
Total copper $\left(\mu \mathrm{g} \mathrm{g}^{-1}\right)$ & $325.1 \pm 9.4$ & $293.9 \pm 10.6$ & $291.7 \pm 13.4$ & $286.4 \pm 11.8$ \\
Total lead $\left(\mu \mathrm{g} \mathrm{g}^{-1}\right)$ & $41.6 \pm 1.08$ & $34.44 \pm 0.97$ & $32.06 \pm 1.83$ & $30.69 \pm 1.58$ \\
\hline
\end{tabular}

Table 2. Changes in nutrient content and heavy metal concentrations due to vermicomposting of different proportions of IS and PM proportions 
Total heavy metal content of the organic substrates decreased due to vermicomposting (Table 2). The extent of decrease in heavy metal content was proportionately increased with the amount of PM added to IS. Among different heavy metals, zinc recorded the maximum decrease in total concentration after vermicomposting followed by $\mathrm{Cr}, \mathrm{Cu}$ and $\mathrm{Pb}$. Though vermicomposting significantly $(\mathrm{P}<0.05)$ reduced total content of different heavy metals, the values were not significantly affected by different PM proportions.

\subsection{Microbial biomass}

Total microbial biomass of the organic wastes was significantly $(P<0.05)$ increased due to vermicomposting (Fig. 1). Periodical analysis indicated an exponential nature of biomass dynamics in organic substrates during vermicomposting. Addition of PM significantly $(\mathrm{P}<$ $0.05)$ increased microbial biomass in final vermicompost. The highest MBC content was registered within 15-30 days of vermicomposting. $\mathrm{MBC}$ of vermicomposts, prepared from $\mathrm{T}_{1}$ and $T_{2}$ were statistically at par. Vermicompost of $T_{3}$, however, recorded significantly $(P<$ 0.05 ) higher MBC as compared to other treatments.

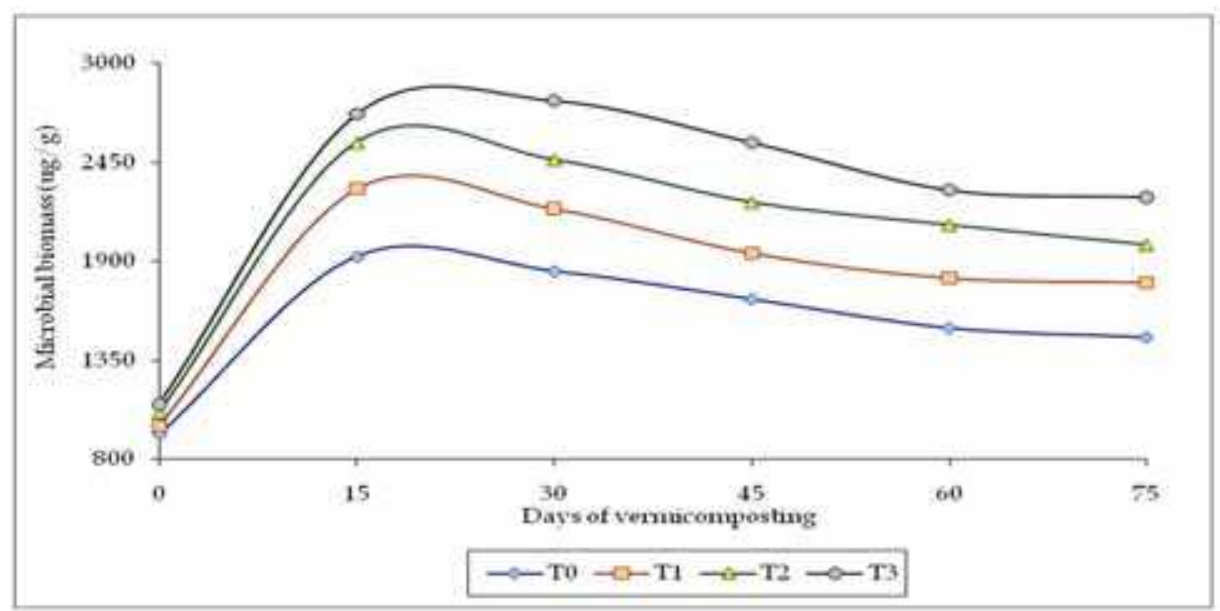

Fig. 1. Periodical changes in microbial biomass carbon (MBC) in IS and PM mixtures during vermicomposting

Periodical analysis revealed the variable pattern of biomass dynamics for total microbial community, fungi and bacteria during vermicomposting of various IS and PM mixtures. Ergosterol content i.e., fungal biomass (FBC) in all the treatments was sharply increased in the first 30 days and thereafter decreased gradually till the end of the vermicomposting process (Fig. 2). However, the final fungal biomass of vermicompost was significantly $(\mathrm{P}<$ $0.05)$ higher than that of initial organic substrates. Addition of PM with IS, significantly $(\mathrm{P}<$ 0.05 ) increased fungal biomass of final vermicompost. Vermicompost prepared from $T_{3}$ recorded significantly $(\mathrm{P}<0.05)$ higher $\mathrm{FBC}$ as compared to other treatments and $\mathrm{FBC}$ values of vermicomposts, prepared from $\mathrm{T}_{1}$ and $\mathrm{T}_{2}$, were statistically at par.

Periodical analysis results revealed that total FAME content in vermicompost followed almost same of ergosterol content (Fig. 3). The highest FAME was recorded in $\mathrm{T}_{3}$ treatment and it was significantly higher than other treatments. 


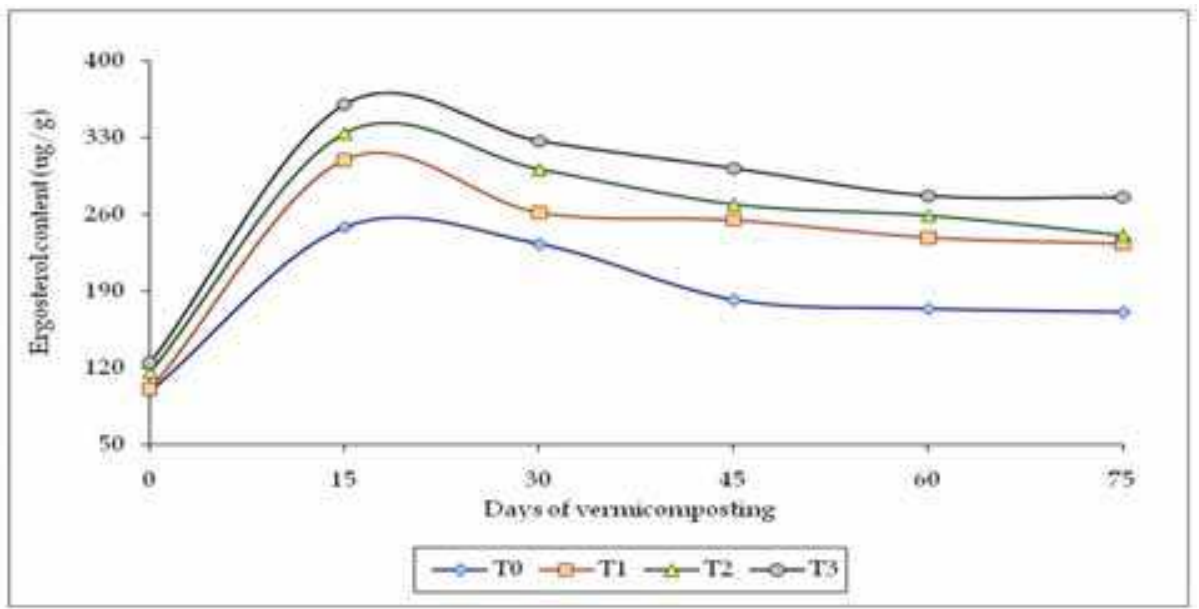

Fig. 2. Periodical changes in ergosterol content in IS and PM mixtures during vermicomposting

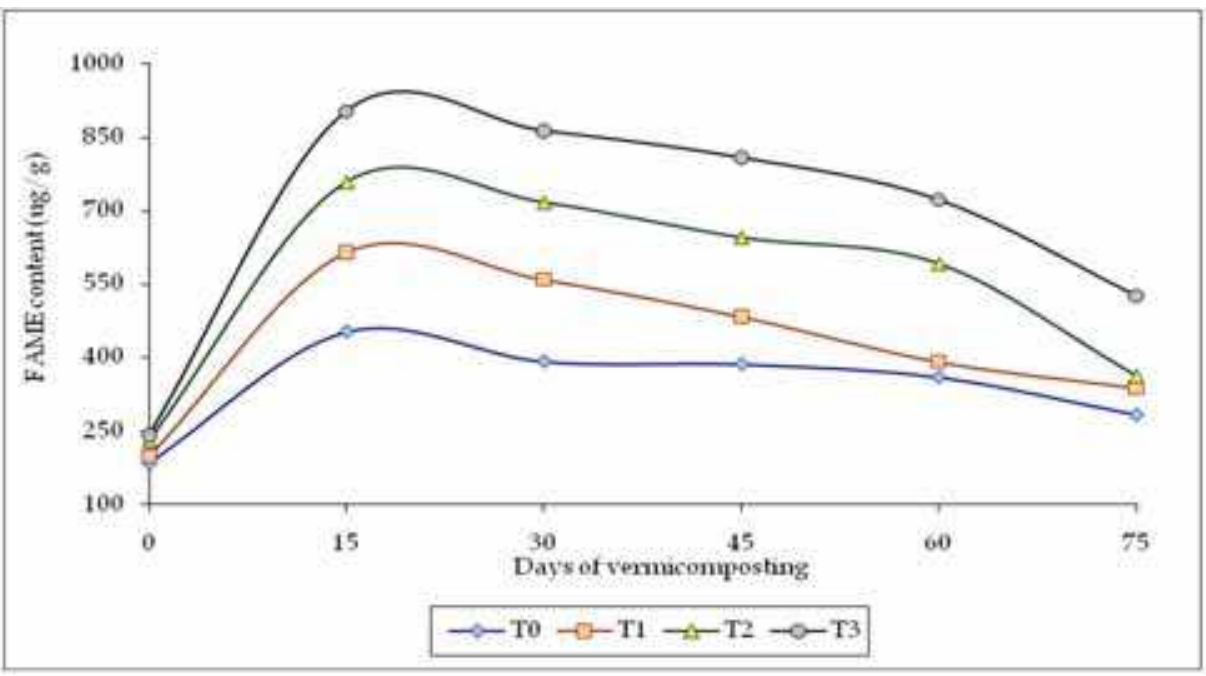

Fig. 3. Periodical changes in total fatty acid methyl esters (FAMEs) content in IS and PM mixtures during vermicomposting

Muramic acid was estimated as an indicator of bacterial biomass. Periodical estimation of muramic acid in the waste mixture revealed a steady increase in the muramic acid content up to 45 days of the process and thereafter it decreased till the end of the process. The final muramic acid contents of vermicomposts, prepared from $\mathrm{T}_{2}$ and $\mathrm{T}_{3}$, were significantly $(\mathrm{P}<$ $0.05)$ higher than that of their initial waste mixtures. In case of $T_{0}$ and $T_{1}$ treatments, muramic acid contents of vermicomposts were statistically at par with that of initial wastes. Analysis revealed that muramic acid contents of vermicomposts, prepared from $T_{0}$ and $T_{1}$ treatments, did not differ statistically among them. 


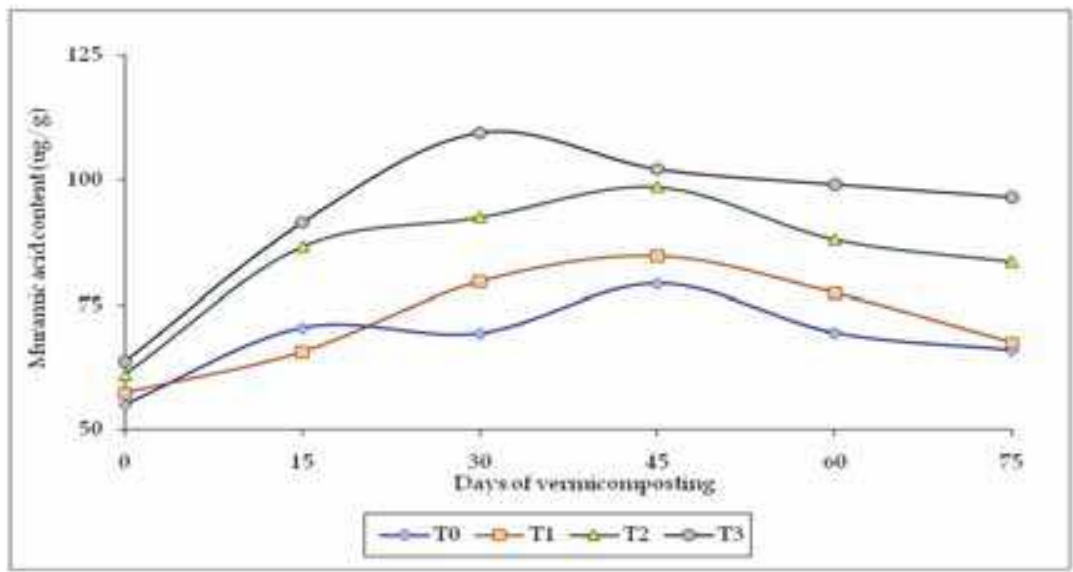

Fig. 4. Periodical changes in muramic acid content in IS and PM mixtures during vermicomposting

\subsection{Plant growth promotion}

Incubation of radish seeds with ethyl acetate extract of vermicomposts for 5 days significantly $(\mathrm{P}<0.05)$ increased root and shoot length of radish as compared to control. Column chromatography of concentrated ethyl acetate extract of vermicomposts yielded 24 fractions. Radish bioassay with all these fractions revealed that 3 fractions $\left(5^{\text {th }}, 7^{\text {th }}\right.$ and $\left.8^{\text {th }}\right)$ out of 24 fractions were able to increase radish root and shoot length as compared to control as well as other fractions (Fig. 5). The root and shoot length of all fractions were presented in Fig. 6. Vigor index, summation of root length and shoot length, is a good indicator for plantgrowth promotion and its highest value was recorded in fraction 5.

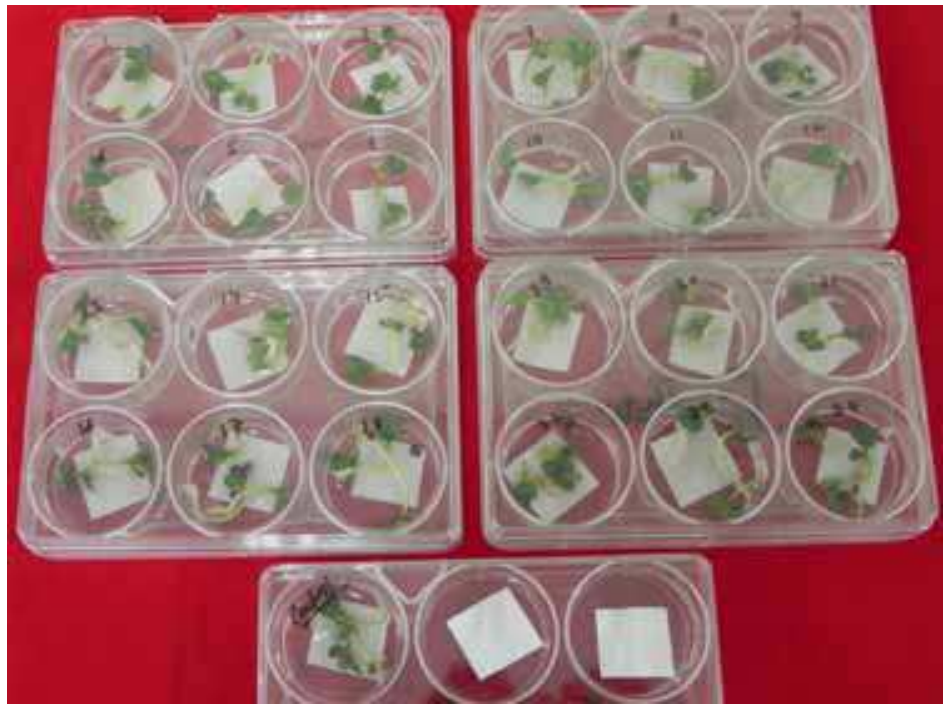

Fig. 5. Radish bioassay test results of different fractions of vermicompost extract 

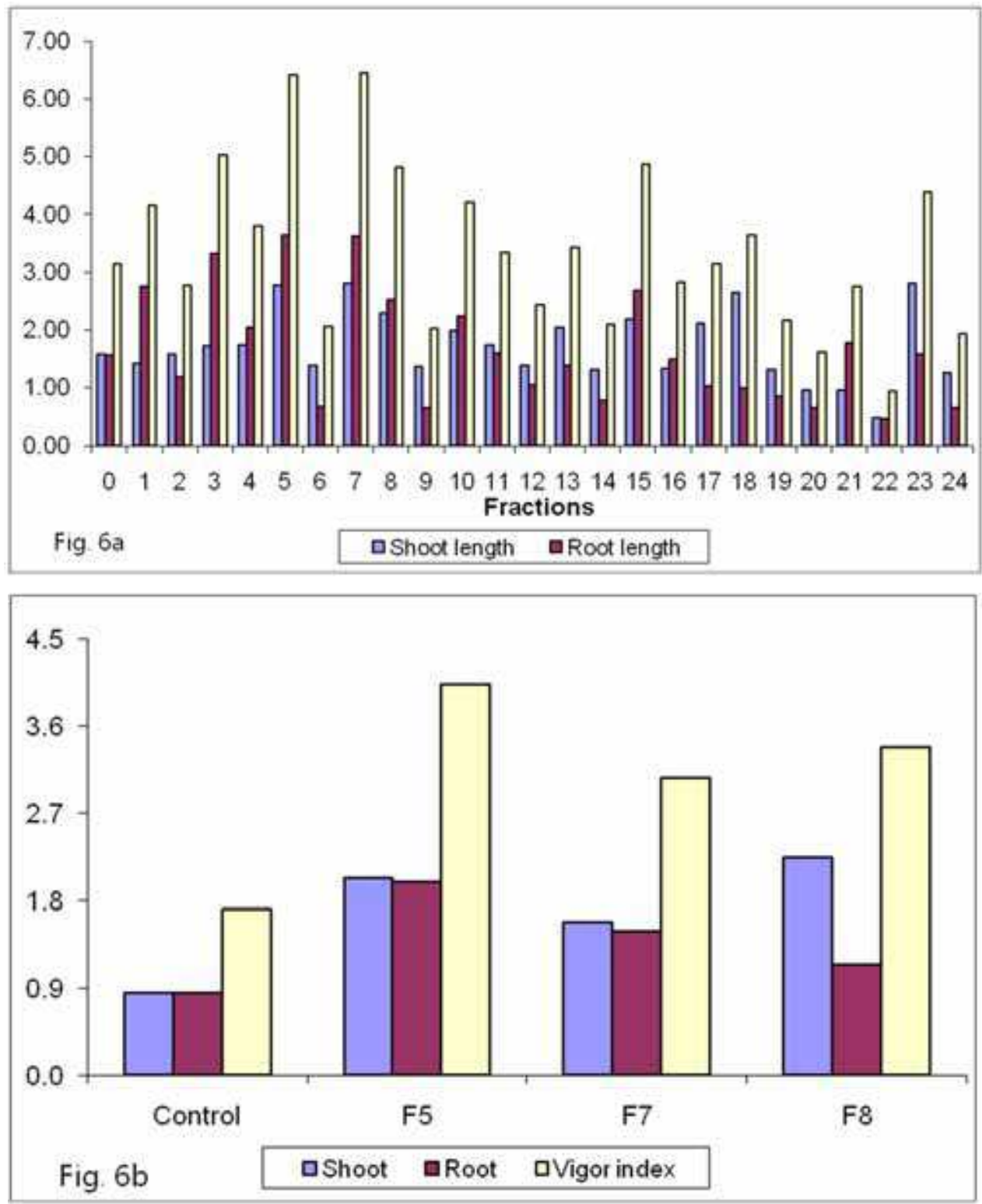

Fig. 6. Root, shoot lengths $(\mathrm{cm})$ vigor indexes of radish seedlings as affected by different fractions obtained after column chromatography

HPLC analysis of these three fractions confirmed the presence of indole acetic acid (IAA) in $5^{\text {th }}$ fraction (Fig. 7). Incubation of serially diluted vermicomposts extract in tryptophanamended broth medium revealed pink colouration after 7 days incubation. Colorimetric analysis indicated the presence of $137 \mu \mathrm{g} \mathrm{IAA} \mathrm{L}^{-1}$ medium after 7 days. 

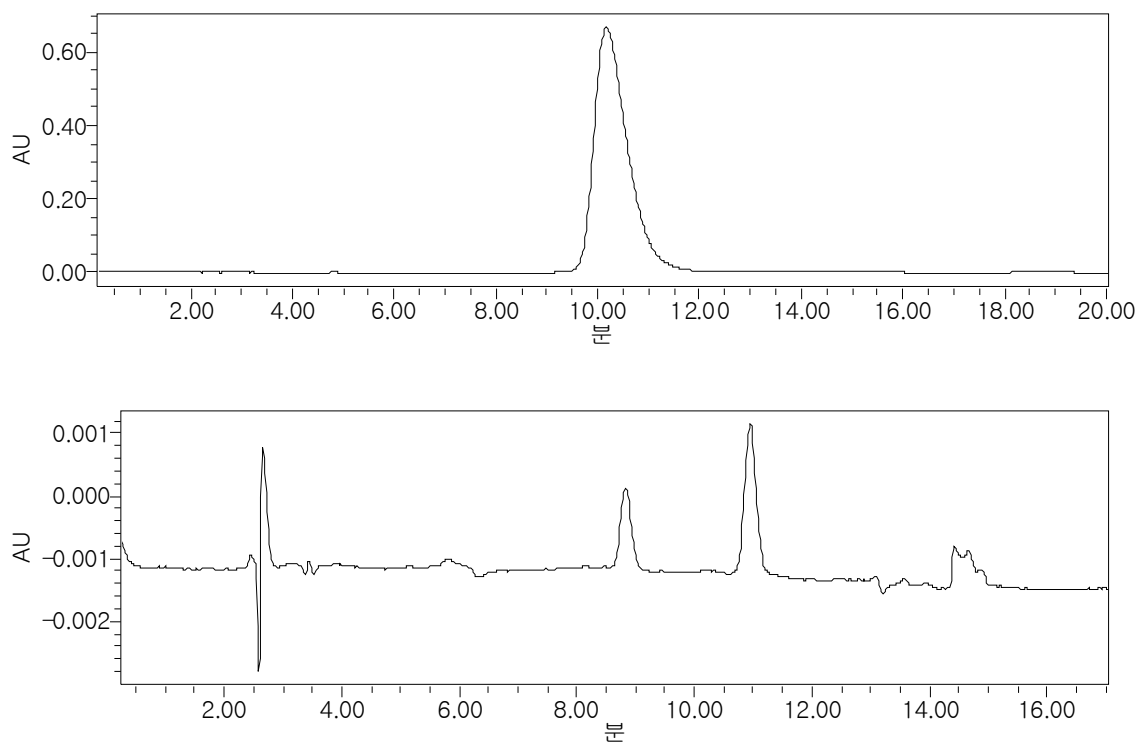

Fig. 7. HPLC chromatogram of standard and fraction 5 for IAA analysis

\section{Discussion}

Vermicomposting is the controlled oxidative decomposition of organic substrates by mutual interaction between earthworm and microorganisms. Cow manure was generally mixed with initial organic wastes to provide easily available energy source and favourable environment to the earthworms. In this experiment, cow manure was replaced by poultry manure (PM) to recycle industrial sludge (IS). Data indicated that proportion of PM determined the quality of final vermicompost. Addition of $10 \%$ and $20 \%$ PM with IS yielded vermicomposts which have significantly $(\mathrm{P}<0.05)$ higher NPK content and lower heavy metals content as compared to other treatments, however, values of these two treatments were statistically at per. PM mixing enhanced the earthworm activity which in turn increased the rate of organic substrate decomposition. During mineralization, dry mass of organic substrates was lost as $\mathrm{CO}_{2}$ by oxidative decomposition (Viel et al., 1987). Addition of PM lowered the C/N ratio of initial waste mixture. Tripathi and Bhardwaj (2004) proposed that narrower $\mathrm{C} / \mathrm{N}$ ratio facilitates earthworm feeding, which in turn enhanced the rate of organic matter decomposition.

Organic substrates were stabilized by action of microorganisms in the presence of earthworms during vermicomposting (Edwards and Fletcher, 1988). Epigeic earthworms are generally used for organic waste decomposition and they consume microorganisms specially fungi to satisfy their nitrogen requirement. Pramanik and Chung (2011) also found similar results during vermicomposting of fly ash and vinasse mixture. This increase in microbial biomass indicated that vermicomposting facilitates microbial proliferation in final stabilized product. Ergosterol content of organic substrates was multiplied by conversion factor 5.4 (Klamer and Baath, 2004) to calculate fungal biomass (FB) in it. Though 
earthworms selectively consume fungi as their food, increased fungal biomass during vermicomposting suggested that not all the fungi were killed during passage through earthworm guts, in fact the rate of germination of fungal spores was probably enhanced under favourable condition of earthworm guts (Hendrikson, 1990). Comparisons of fungal biomass, calculated from ergosterol content, with total FAME content of decomposing substrates gave a significantly positive correlation value $\left(\mathrm{r}=0.921^{*}\right)$. The ratio of these two parameters could be arranged following a linear regression with a mean value 2.71 (standard deviation $=0.48$ ). Since FAME analysis is more precise method to estimate FBC, this conversion factor (2.71) could be used to calculate FBC of vermicompost from its FAME values.

Muramic acid occurs naturally as $\mathrm{N}$-acetyl derivatives in peptidoglycan, the characteristic polysaccharide composing bacterial cell wall. In this experiment, muramic acid was estimated as a marker molecule for bacterial biomass in decomposing waste mixture. Data of periodical muramic acid content indicated a steady increase in bacterial biomass during vermicomposting. Muramic acid content was proportionately increased with increasing PM ratio in initial waste mixture and $20 \% \mathrm{PM}$ addition recorded significantly $(\mathrm{P}<0.05)$ higher muramic acid content in final vermicomposts. Though addition of $10 \%$ and $20 \%$ PM with IS produced vermicomposts having significantly higher NPK content, but based on microbial status of vermicomposts, it could be concluded that 20\% PM mixing with IS was probably the optimum combination to obtain the best quality vermicomposts.

In this study, conversion factor of muramic acid to bacterial biomass was biomass was estimated by assuming that fungi and bacteria are the major microbial community present in vermicompost and bacterial biomass was calculated by subtracting fungal biomass from total microbial biomass. This bacterial biomass was compared with muramic acid content and it had shown significant correlation $\left(\mathrm{r}=0.918^{*}\right)$ between these two parameters. Analysing indicated that ratios of calculated bacterial biomass and muramic acid had the mean value 8.22 with standard deviation 0.88 . Therefore, this value (8.22) could be used as a conversion factor for calculating bacterial biomass from muramic acid of vermicompost.

Several researchers found that application of vermicompost had hormone-like effect on plants (Arancon et al., 2004). The results of this experiment confirmed that vermicompost possessed IAA-producing microorganisms which in turn facilitated plant growth through IAA production.

\section{Conclusion}

Vermicomposting is a rapid and safe process to recycle IS and PM mixture into nutrient-rich soil amendment. Passage of organic substrates through earthworm guts also reduced total heavy metal content in it. Microbiological diversity of organic substrates was also modified during vermicomposting. Both fungal and bacterial biomass was increased during vermicomposting of IS and PM mixture. Results indicated the presence of IAA-producing bacteria in vermicomposts, which enabled it to promote plant growth. Mixing of $10 \%$ PM with IS was probably the optimum condition to obtain the best quality vermicomposts.

\section{Acknowledgement}

This work was supported by the Institute of Agriculture and Life Sciences, Gyeongsang National University, South Korea and also by scholarships from the BK21 program, Ministry of Education and Human Resources Development, South Korea. 


\section{References}

Anonymous (2004). Statistics on Production and Outlets of Sewage Sludge. Ministry of Environment, Republic of Korea, pp. 11-12.

Arancon, N.Q., Edwards, C.A., Atiyeh, R., Metzger, J.D. (2004). Effect of vermicomposts produced from food waste on the growth and yields of greenhouse peppers. Bioresource Technology, volume 93, issue 2 (June 2004), pp. 139-144, ISSN: 0960-8524.

Bansal, S., Kapoor, K.K. (2000). Vermicomposting of crop residues and cattle dung with Eisenia foetida. Bioresouorce Technology, volume 73, issue 1 (May 2000), pp. 95-98, ISSN: 0960-8524.

Begum, A., Krishna, H. (2010). Management of municipal sewage sludge by vermicomposting technique. International eburnal of ChemTech Research, volume 2, issue 3 (July-September 2010), pp. 1521-1525, ISSN: 0974-4290.

Bremner, J.M., Mulvaney, R.G. (1982). Total Nitrogen. In: Methods of Soil Analysis, Page, A.L., Miller, R.H., Keeney, D.R. (Eds.), Part 2, American Society of Agronomy, Madison, pp. $575-624$.

Chitdeshwari, T., Savithri, P. (2004). Quality of sewage biosolid composts and their impact on the yield of maize. Indian eburnal of Agricultural Research, volume 38, issue 2 (June 2004), pp. 147-150, ISSN: 0367-8245.

Coker, E.G., Hall, J.E., Carlton-Smith, C.H., Davis, R.D. (1987). Field investigations into the manurial value of lagoon-matured digested sewage sludge. The eburnal of Agricultural Science, volume 109, issue 3 (December 1987), pp. 467-478.

Edwards, C.A., Fletcher, K.E. (1988). Interaction between earthworms and microorganisms in organic matter breakdown. In: Biological Interactions in Soil, Edwards, C.A. (Ed.), Elsevier, New York, pp. 235-247.

Gesser, M.O., Bauchrowitz, M.A., Escautier, M. (1991). Extraction and quantification of ergosterol as a measure of fungal biomass in leaf litter. Microbial Ecology, volume 22, issue 1 (December 1991), pp. 285-291, ISSN: 1432-184X.

Guerrant, G.O., Moss, C.W. (1984). Determination of monosaccharides as aldononitrile, Omethyloxime, alditol and cyclitol acetates derivatives by gas chromatography. Analytical Chemistry, volume 56, issue 4 (April 1984), pp. 633-638, ISSN: 0003-2700.

Hendrikson, N.B. (1990). Leaf litter selection by detritivore and geophagous earthworms. Biology and Fertility of Soils, volume 10, issue 1 (October 1990), pp. 17-21, ISSN: 1432-0789.

Hill, G.T., Mitkowski, N.A., Aldrich-Wolfe, L., Emele, L.R., Jurkonie, D.D., Ficke, A., Malodonado-Ramirez, S., Lynch, S.T., Nelson, E.B. (2000). Methods for assessing the composition and diversity of soil microbial communities. Applied Soil Ecology, volume 15, issue 1 (August 2000), pp. 25-36, ISSN: 0929-1393.

Jackson, M.L. (1973). Soil Chemical Analysis. Prentice Hall Private Ltd., New Delhi, India.

King, J.D., White, D.C. (1977). Muramic acid as a measure of microbial biomass in estuarine and marine samples. Applied and Environmental Microbiology, volume 33, issue 4 (April 1977), pp. 777-783, ISSN: 0099-2240.

Klamer, M., Baath, E., 2004. Estimation of conversion factors for fungal biomass

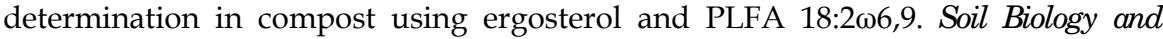
Biochemistry, volume 36, issue 1 (January 2004), pp. 57-65, ISSN: 0038-0717. 
McGrath S.P. (1994). Effects of heavy metals from sewage sludge on soil microbes in agricultural ecosystems. In: Toxic Metals in Soil-Plant Systems, Ross S. M., (ed.), Chichester, John Wiley, pp. 242-274.

Nelson, D.W. and Sommers, L.E., 1982. Total carbon and organic carbon. In: In: Methods of Soil Analysis, Page, A.L., Miller, R.H., Keeney, D.R. (Eds.), Part 2, American Society of Agronomy, Madison, pp. 539-579.

Pramanik, P., Chung, Y.R. (2011). Changes in fungal population of fly ash and vinasse mixture during vermicomposting by Eudrilus eugeniae and Eisenia fetida: Documentation of cellulose isozymes in vermicompost. Waste Management, in Press (DOI: 10.1016/j.wasman.2010.12.017).

Schutter, M.E., Dick, R.P. (2000). Comparison of fatty acid methyl ester (FAME) methods for characterizing microbial communities. Soil Science Society of America eburnal, volume 64, issue 5 (September - October 2000), pp. 1659-1668, ISSN: 1435-0661.

Sparling, G.P., West, A.W. (1988). Modifications to the fumigation extraction technique to permit simultaneous extraction and estimation of soil microbial $\mathrm{C}$ and $\mathrm{N}$. Communications in Soil Science and Plant Analysis, volume 19, issue 3 (February 1988), pp. 327-344, ISSN: 1532-2416.

Triphathi, G., Bhardwaj, P. (2004). Decomposition of kitchen waste amended with cow dung using an epigeic species (Eisenia fetida) and an anecic species (Lampito mauritii). Bioresource Technology, volume 92, issue 2 (April 2004), pp. 215-218, ISSN: 09608524.

Vance, E.D., Brookes, P.C., Jenkinson, D.S. (1987). An extraction method for measuring soil microbial biomass C. Soil Biology and Biochemistry, volume 19, issue 6 (March 1987), pp. 689-696, ISSN: 0038-0717.

Viel, M., Sayag, D., Andre, L. (1987). Optimization of agricultural, industrial waste management through in-vessel composting. In: Compost: Production, Quality and Use, deBertodi, M. (Ed.), Elsevier Applied Sciences, Essex, pp. 230-237.

Yasir, M., Aslam, Z., Kim, S.W., Lee, S.-W., Joen, C.O., Chung, Y.R. (2009). Bacteria community composition and chitinase gene diversity of vermicompost with antifungal activity. Bioresource Technology, volume 100, issue 19 (October 2009), pp. 4396-4403, ISSN: 0960-8524.

Zhang, X., Amelung, W. (1996). Gas chromatographic determination of muramic acid, glucosamine, mannosamine, and galactosamine in soils. Soil Biology \& Biochemistry, volume 28, issue 9 (September 1996), pp. 1201-1206, ISSN: 0038-0717. 


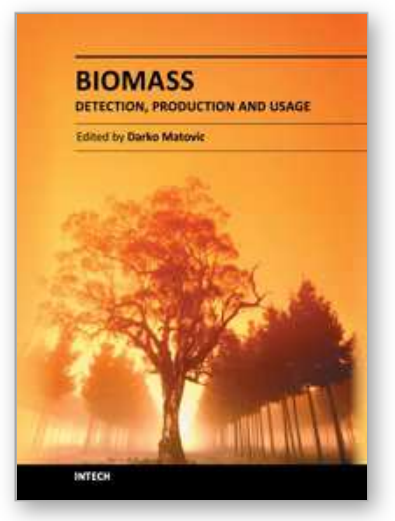

\author{
Biomass - Detection, Production and Usage \\ Edited by Dr. Darko Matovic
}

ISBN 978-953-307-492-4

Hard cover, 496 pages

Publisher InTech

Published online 09, September, 2011

Published in print edition September, 2011

Biomass has been an intimate companion of humans from the dawn of civilization to the present. Its use as food, energy source, body cover and as construction material established the key areas of biomass usage that extend to this day. Given the complexities of biomass as a source of multiple end products, this volume sheds new light to the whole spectrum of biomass related topics by highlighting the new and reviewing the existing methods of its detection, production and usage. We hope that the readers will find valuable information and exciting new material in its chapters.

\title{
How to reference
}

In order to correctly reference this scholarly work, feel free to copy and paste the following:

Prabhat Pramanik, Sang Yoon Kim and Pil Joo Kim (2011). Changes in Fungal and Bacterial Diversity During Vermicomposting of Industrial Sludge and Poultry Manure Mixture: Detecting the Mechanism of Plant Growth Promotion by Vermicompost, Biomass - Detection, Production and Usage, Dr. Darko Matovic (Ed.), ISBN: 978953-307-492-4, InTech, Available from: http://www.intechopen.com/books/biomass-detection-production-andusage/changes-in-fungal-and-bacterial-diversity-during-vermicomposting-of-industrial-sludge-and-poultry-ma

\section{INTECH}

open science | open minds

\section{InTech Europe}

University Campus STeP Ri Slavka Krautzeka 83/A 51000 Rijeka, Croatia Phone: +385 (51) 770447

Fax: +385 (51) 686166 www.intechopen.com

\section{InTech China}

Unit 405, Office Block, Hotel Equatorial Shanghai No.65, Yan An Road (West), Shanghai, 200040, China 中国上海市延安西路65号上海国际贵都大饭店办公楼405单元 Phone: +86-21-62489820

Fax: +86-21-62489821 
(C) 2011 The Author(s). Licensee IntechOpen. This chapter is distributed under the terms of the Creative Commons Attribution-NonCommercialShareAlike-3.0 License, which permits use, distribution and reproduction for non-commercial purposes, provided the original is properly cited and derivative works building on this content are distributed under the same license. 